https://doi.org/10.31426/ijamsr.2018.1.7.713

International Journal of

Advanced Multidisciplinary Scientific Research (IJAMSR) ISSN:2581-4281

\title{
HIGHLIGHTING THE ROLE OF CRITICAL THINKING AND GIVING MORE IMPORTANCE TO ITS ROLE IN ENGLISH LANGUAGE TEACHING FIELD
}

\author{
Nafiseh. Arfaolrafiei \\ Research Schloar, Islamic Azad University, Tehran, Iran. \\ nafise66arfa@gmail.com
}

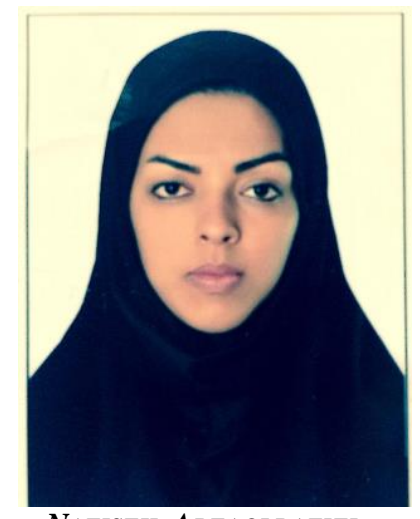

NAFISEH. ARFAOLRAFIEI

Keywords: Critical Thinking,

English language, Teaching

Field, Educational System.

\section{Introduction}

Critical thinking is considered as one of the compulsory

\begin{abstract}
A B S T RA C T
The importance role of critical thinking in education has been investigated for some time. In this study, the role and importance of applying critical thinking in the educational system has been studied. Considering the importance of critical thinking in the world of science today, its benefits are discussed. The lack of the use of cognitive thinking in many of the English language classes and the lack of success will make the role more meaningful. In this article, first, attention is paid to the role and importance of critical thinking, and then benefits of applying a course as critical thinking in English language Teaching Field are discussed. In order to study, 33 Iranian and foreign articles have been used. It is worth mentioning that a number of issues on the subject of critical thinking and the goals and studies of their authors have been mentioned. The result shows that in order to improve and develop the critical thinking of learners, critical thinking as a course can be beneficial to add in the English Teaching System. According to all the research that have been done on critical thinking, the existence of a critical thinking in the teaching system can help to improve the level of language proficiency, to increase the awareness of teachers and to develop their abilities in teaching critical thinking to learners.
\end{abstract}

Citation: Nafiseh. Arfaolrafiei (2018). Highlighting The Role Of Critical Thinking And Giving More Importance To Its Role In English Language Teaching Field. International Journal of Advanced Multidisciplinary Scientific Research (IJAMSR ) ISSN:2581-4281 Vol 1, Issue 7, September, 2018, \#Art.713, pp 21-29 


\section{International Journal of Advanced Multidisciplinary Scientific Research (IJAMSR) ISSN:2581-4281}

(Halpern, 1993). Students will improve their critical thinking when teachers use appropriate instructional methods and curriculum materials (Gadzella\&Masten, 1998; Halpern, 1993; McMillan, 1987), active learning strategies (Kim, 2009), and student-to-student and pupilto-instructor interactions (Cooper, 1995; Howe \& Warren, 1989). Critical thinking can provide you with a more insightful understanding of yourself. It will provide you an opportunity to be objective, less emotional, and more open-minded as you appreciate others' thoughts and thoughts. By thinking ahead, you will acquire the confidence to give new perspectives and fresh insights into burdensome concerns. Ennis ("Critical thinking" 5) defines critical thinking as a thoughtful and fair process whose primary aim is to reach sensible decisions about what to trust or what to do.

Applying the critical thinking skills can be beneficial for learners in order to make them smarter and for teachers to be more knowledgeable. Based on some researches' results, critical thinking skills help learners to achieve higher levels in their study and profession and able to effectively handle leadership roles .Also, some oral questions have been asked about importance of critical thinking and applying it on the educational system , most of the teachers and students from 4 Univesities and 5 institutes were not aware of this issue . This study can be useful for teachers and learners to be familiar with some main roles of this issue and improve critical thinking strategies such as explicit instruction, collaborative or cooperative learning, modeling, and constructivist techniques for promoting level of their teaching and learning. Not smarter in some particular matter, mind you, just smarter in general. Critical Thinking. A great quantity of scholarly literature is available on the world wide web on the subject of critical skills.
Critical thinking researchers maintain that critical thinking skills and abilities can be instructed. Halpern (1998) offers evidence of two instructional programs aimed at improving the critical thinking skills and abilities of college students. A number of researchers have recommended using particular instructional strategies to encourage the development of critical thinking skills and abilities, such as explicit instruction, collaborative or cooperative learning, modeling, and constructivist techniques. Critical thinking skills relate to various other significant student learning issues, such as metacognition, motivation, collaboration, and creativity. Metacognition (or thinking about thinking) supports critical thinking in that students who can monitor and measure their own thought processes are more likely to exhibit high-quality thinking. In addition, the ability to critically evaluate one's own arguments and reasoning is necessary for self-regulated learning. Motivation supports critical thinking in that students who are motivated to learn are more likely to persist at tasks that call for critical thinking. In students possessing critical thinking dispositions, such as willingness to consider diverse perspectives, may make better collaborators, and chances for collaboration may promote higher-order thinking. Finally, creativity requires the ability to critically evaluate intellectual products, and critical thinking requires the open-mindedness and flexibility that is characteristic of creative thinking. Although learning progressions of critical thinking skills and dispositions do not yet (and may never) exist, at least one researcher has tied the progression of critical thinking skills to cognitive development in general and metacognition in particular. Empirical research in the area of metacognition suggests that people begin building up critical thinking competencies at a really immature age and continue to improve them (or not) 


\section{International Journal of Advanced Multidisciplinary Scientific Research (IJAMSR) ISSN:2581-4281}

over the course of a life. Many adults exhibit deficient reasoning and neglect to think critically. Yet, in theory, all people-from all intellectual ability levels and from the very young to the very old - can be taught to think critically. Empirical evidence suggests that children are, in fact, much more capable of critical thought than at one time anticipated.

If teachers are to be successful in promoting the growth of critical thinking skills, explicit instruction in critical thinking needs to be included in the curriculum, whether that instruction occurs as a stand-alone course, is infused into matter-matter content, or both. Cooperative or collaborative learning methods hold promise as a means of stimulating cognitive development, along with constructivist approaches that place students at the heart of the learning procedure. Teachers should model critical thinking in their instruction and provide concrete examples for illustrating abstract concepts that students will find salient. Assessing critical thinking skills poses challenges that are alike to those in other measurement contexts.

Looking at all of the advantages, the importance of delivering a course book as a core and source of information about critical thinking concept for English Teaching teachers and scholars of English Teaching should be taken into account.

\section{Literature Review}

The literature on critical thinking has roots in two main academic disciplines: philosophy and psychology (Lewis \& Smith, 1993). Sternberg (1986) has also noted a third critical thinking strand within the field of education.Definitions of critical thinking emerging from the philosophical tradition include "the propensity and skill to engage in an activity with reflective skepticism" (McPeck, 1981, p. 8);"reflective and reasonable thinking that is focused on deciding what to believe or do" (Ennis, 1985, p. 45).

Critical thinking is defined in numerous ways, but typically involves the power to do some or all of the following: "identify central issues and assumptions in an argument, recognize important relationships, make correct inferences from data, deduce conclusions from information or data provided, interpret whether conclusions are warranted on the basis of the data given, and evaluate evidence or authority" (Pascarella\& Terenzini,1991, p. 118). The focus of Kuhn's (1999) Developmental Model of Critical Thinking is Metaknowing, knowing about one's own as well as others' knowing, and is further divided into three categories identified as metacognitive, metastrategic, and epistemologicalunderstanding. Individual's epistemological commitments, metacognitive processing of behavior, and critical thinking are integral components of controlling learning (Tsai, 2001). Metacognition operates on an individual's base of declarative knowledge (know that), while metastrategic knowing operates with an individual's procedural knowledge (knowing how) (Kuhn, 1999). Epistemological knowing focuses on general philosophical aspects and personal aspects. Although the three classes will be further examined individually, it is important to recognize the views of each appear throughout the broad focus of meta-knowing (Kuhn, 1999).

The history of researches on thinking depends upon the time that human beings recognized that they 


\section{International Journal of Advanced Multidisciplinary Scientific Research (IJAMSR) ISSN:2581-4281}

commemorate. Thinking is one of the characteristics that separate humans from other living organisms. Thinking is the manipulation or transformation of some internal representation (Halpern. 2003, p.84). She says that when we start thinking, we use our knowledge to achieve some objective. In this sense thinking ability is the basic form of our life because all of us need to achieve an objective; on the other hand humans have relations in society and whereas nobody is exclusively.

Descartes argued that thinking is reasoning, and that reason is a concatenation of simple ideas linked by applying rigid rules of logic (McGregor, 2007). His findings regarding neurological transmissions between receptors andaffecters in various vertebrates led him to declare 'Cogito ergo sum', which translated means 'I think therefore iamb' (Gaukroger, 2003). Thinking critically and thinking creatively can be seen as the same but undoubtedly there are basic differences between two thinking styles. Creativitymasters a process of making or producing, criticality a process of assessing or judging. The very definition of the word "creative" implies a critical component. When we understand critical and creative thought truly and deeply, we recognize them as inseparable, integrated, and unitary (Paul \& Elder, 2008). There has always been a strand of educational thought that held that the strengthening of the child's thinking should be the chief business of the schools and not just an incidental outcome - if it happened at all (Lipman, 2003).

According to Critical Thinking Cooperation (2006) critical thinking is an ability which is beyond memorization. When students think critically, they are encouraged to think for themselves, to question hypotheses, to analyze and synthesize the events, to go one step further by developing new hypotheses and test them against the facts. Questioning is the cornerstone of critical thinking which in turn is the source of knowledge formation and as such should be taught as a framework for all learning. Students are frequently conditioned in their approach to learning by experiences in teacher-centered, textbook-driven classrooms (Sharma \& Elbow 2000).

Critical thinking individuals are people who research, question, refuse the information's as it is, active, think analytically and synthetically, evaluate the information and explain with true basis, treat open-minded and aware of thinking processes. . If you develop the ability to analyses people's attempts to persuade so that you can accurately interpret what they are saying or writing and evaluate whether ornot they are giving a good argument then you can begin to liberate yourself from accepting what others try to persuade you off without knowing whether you actually have a good reason to be persuaded (Bowell \& Kemp,2002).

Initial studies conducted on critical thinking began in the years of the 1960s. Researchers have thought to explain critical thinking with two main disciplines thorough these studies. Philosophical approach has dwelled on norms of sound thinking, the concept and motive of human thought and cognitive skills necessary for an objective worldview; while the psychological approach has dwelt on thinking and experimental studies thinking, individual differences in learning thinking and the concept of problem solving which is a composition of critical thinking. Now I will give a few examples of the studies of critical thinking. Kürüm (2002) put forward a study at the AnadoluUniversity Education Faculty. The goal of Kürüm's study was to identify critical thinking 


\section{International Journal of Advanced Multidisciplinary Scientific Research (IJAMSR) ISSN:2581-4281}

abilities and the levels of thinking abilities that constitute this ability and the factors which influenced critical thinking of teacher trainees studying at the Anadolu University Education Faculty. The outcomes of the field indicated that teacher trainees' critical thinking powers and all grades of thinking abilities were at mid- story and that these abilities were affected by different factors such as age, high school types graduated, score type and tier in the university entrance exam, the program being studied, education and income level of the menage, and activities held for training themselves

Critical thinking is essential for today's life, where individuals daily face unlimited amounts of data, complex problems, and rapid technological and societal varieties. The increased emphasis on implementation of an instructional model development based on the cognitive approach to enhance trainee students' critical thinking and critical thinking, teaching ability requires the dynamic involvement of trainee students in their learning processes, not only enabling them to run together but also supplying them with opportunities to select learning activities and to assess their own operation. Trainee students in learning teams take responsibility for particular partitions of the labors and share what they ascertain with their groups in a way that group members will cover. In particular, trainee students construct new knowledge using their own experiences.

\section{Discussion}

Critical thinking has a main role in all educational systems. The level of education is not important, but how to apply, how to use, how to understand strategies are more important these days. Based on some researches on critical thinking, using critical thinking course for English Teacher Education can be beneficial and applicable. Teachers can develop an instructional cognitive model to help learners. It's very important instructors, in the University keep advising their learners to develop Critical Thinking skills. Critical thinking- a term that is applied to denote thorough or exhaustive thinking and is chiefly used in the sphere of teaching. Inside the fabric of scientific agnosticism, the process of critical thinking requires the careful acquisition and interpretation of data and the exercise of it to get to a well-justified end. The concepts and precepts of critical thinking can be used to whatever context or case, but simply by meditating upon the nature of that diligence.

In recent decades, a popular topic for research, debates, forums and conferences on the function of pedagogy is the need to assist students develop critical thinking skills. Important theorists, supporters and researchers on critical thinking defend itself fundamental role in all different fields and knowledge domains, as well as in all life settings where human beings develop, such as work, education, family, friends, and community (Moseley et al 10; Butler 721). Paul and Elder (4) state that thinking is an innate human beings' capacity.

However, thinking on its own can be influenced, distorted and biased. Also, they advocate that people's life quality and everything they create, produce and build, depends on the quality of thinking. Thus, excellent critical thinking skills and dispositions must be gradually developed.

Concern about the need to assist students develop critical thinking skills has increased over the last decades because of the student exit profile to face the task market 


\section{International Journal of Advanced Multidisciplinary Scientific Research (IJAMSR) ISSN:2581-4281}

and make do with the needs of 21 st century society which is characterized by rapid changes and advances not only in the technological aspect, but in social and economic matters where knowledge is critical for a nation growth (Crenshaw, Hale and Harper 14).

Sam AunVong a, *, WareeratKaewurai in 2017 investigated on the instructional model development to enhance critical thinking and critical thinking, teaching ability of trainee students at regional teacher training center in Takeo province, Cambodia. The primary aims of this research were to prepare, carry out, and evaluate an instructional model based on the cognitive approach to enhance critical thinking among trainee students and to grow their abilities in teaching critical thinking to learners. The model was designed utilizing 4 main components of research and growth operations and implemented with 15 trainee students whose majors were English and Khmer at the Regional Teacher Training Center. The main purposes of this research were: to develop an instructional model, to implement the developed instructional model, to evaluate the developed instructional model based on the cognitive approach to enhance critical thinking among trainee students and to develop their abilities in teaching critical thinking to learners.

Appropriate instruction was extremely successful in fostering trainee students' critical thinking and developing their abilities in teaching critical thinking. To infuse traineestudents with critical thinking skills and critical thinking, teaching ability is to think of them not as receivers of information, but as users of information. Any learning instruction or environment that actively engages trainee students in the investigation of information and the application of knowledge will advance their critical thinking skills and heighten their abilities in teaching critical thinking. These descriptions and illustrations are congruent with those on critical thinking expressed by Geertsen (2003). In using critical thinking and critical thinking, teaching, one learns to make critical judging, examine some claim or assertion, listen to or to collect evidence in support of the claim, determine the strength of the arguments derived from the evidence, assess the underlying assumptions and possible biases supporting the claim, and to arrive at a judgment and a course of action where appropriate.

Scott A. DeWaelsche in (2015) investigated on Critical thinking, questioning and student engagement in Korean university English courses.In this study has been explored that the viability of higher-level questioning in student-centered activities to elevate critical thinking and increase student engagement among Korean university English majors. The author examines research that identifies limitations for Korean students associated with their reluctance to speak or share opinions in class due to sociocultural influences in the classroom. Participants in the study posed and responded to higher-level questions in structured, small-group conversation activities.

Design Using the mixed-methods approach in this study, both quantitative and qualitative research was conducted and data from both forms of research were analyzed (Creswell, 2014). The results of the study were mixed regarding the cultural and institutional challenges outlined above. While there were instances of limited student participation, in many of these cases it was the result of a limitation in language ability or difficulty understanding the material. Although questioning can be an efficient tool for any stratum of the language learner, the higher-level questioning and critical thinking 


\section{International Journal of Advanced Multidisciplinary Scientific Research (IJAMSR) ISSN:2581-4281}

activities that built up this study are not advocated for students below the medium stage.

As Lee et al. (2014) suggested on higher educational institutions may be better at developing compliant transmitters for knowledge maintenance, rather than pioneering leaders who are transformers for innovation (p. 144). The findings in this study confirm that obstacles associated with sociocultural transfer do, in fact, exist. While debate persists over the viability of CT in Korean classrooms, i matter is evident: Korean university students excel in these activities when challenged to act thus. There were many examples of quality, critical responses to higher-level questions; there were many examples of students actively engaged in student-centered learning activities; and there were many examples of student success. Although some students struggled in the present study for the variety of reasons discussed above, the majority of participants succeeded, and many of those excelled.

Kate Wilson in 2016 investigated on Critical reading, critical thinking: delicate scaffolding in English for academic purposes. The report indicated that critical reading instruction can be understood in different ways, but that nurturing students' critical dispositions, in particular, requires delicate scaffolding to support their growth as critical meaning-makers. Such scaffolding pushes students to develop deeper skills and criticality, yet enables them to feel safe in the transcultural contact zones in which they are taking part. Critical thinking is at the heart of tertiary education, and is likewise a key focus of university preparation courses. In particular, developing the ability to read - and to read critically- is vital for aspiring university students. Courses in English for Academic Purposes (EAP) generally include some attention to critical reading, but how this is conceived and realized varies considerably. This paper reports on the findings of an ethnographic study of three EAP teaching-learning contexts in Australia and relates the pedagogy of these classrooms to theories of critical thinking identified by Davies and Barnett (2015). All three EAP contexts focused to some extent on cognitive skills such as identifying main ideas, but teachers differed in their approach to criticality and attention to critical pedagogy.

This paper used three ethnographic case studies to explore how EAP teachers realize their teaching of critical reading. Three university preparation EAP institutions in Australia were invited to take part in the survey as being representative of the industry, and a volunteer teacher came forward in each establishment. All three teachers were experienced teachers of EAP, well respected by their peers, and qualified with Masters Degrees in TESOL or Applied Linguistics. Ethics clearance was obtained from all the institutions involved and both teachers and students all gave signed agreement to participate. Pseudonyms are used throughout this paper.

The researcher wrote that Teachers and institutions can develop many different approaches to curricula and to pedagogy in response to their students, their contexts, and their own beliefs and personalities. Critical thinking skills, critical and critical pedagogy all have something to give. By providing delicate scaffolding and maintaining high engagement, our EAP students can become better critical readers and more conscious thinkers as they advance towards their future works.

Murat KARAKOÇ in 2016 investigated on the significance of critical thinking ability in terms of 


\section{International Journal of Advanced Multidisciplinary Scientific Research (IJAMSR) ISSN:2581-4281}

education. This study explained critical thinking ability in terms of educational processes and the importance of thinking critically for a student who attends any education program. Developing the ability to think critically is an important element for modern education approaches and models. This study intends to give a framework on the concept of thinking critically while teaching or learning. This study is limited to the literary description of the critical thinking subject. The world is getting both more technical and more complex day by day, that's why the necessity for education increases for each growing generation. The researcher concluded that Critical thinking is no doubt necessary in every field of life, but especially for professions that occupy with people. Finkelman (2001) took the attention and emphasized the importance that the people who work in the field of human health, especially the people who directly intervene in the person's life like psychologists, counsellorsand educationalists have to be critical thinkers in both practice and management. In order for teachers and counselors to be able to implement critical thinking into their classrooms, they must first be committed to critical thinking and its philosophy.

Olga LucíaEnciso, D. Enciso, M, doze in 2017 investigated on Critical thinking and its importance in education. This article reviews some conceptions of critical thinking and highlights its importance of education. Description: First, it gives some philosophical and psychological approaches to critical thinking and their influence in international and national educational policies as a way of fostering active citizenship and in turn sustainable development. Second, it plays up the relation between critical thinking and Content and Language Integrated Learning. Third, the authors of this article insist on the vital role teachers have on developing critical thinking. Based on this paper teachers, to play a decisive role in changing the spoonfeeding education paradigm and help our learners develop critical thinking skills and foster human values. Critical thinking skills and subject matter are not mutually exclusive but complementary. Our world needs people who really care about how to restore integrity, promote welfare, equity and social justice; our world needs critical thinkers.

\section{Conclusion}

Regarding those researches and literature of critical thinking, it will be shown that applying critical thinking course in the field of English Teaching help teachers and learners to discover, to understand, to make decision and solve the problems logically. The literature demonstrated that this issue is very beneficial to investigate and applying a course can be impressive for English language teachers and learners. It's better to learn all knowledge related to critical concept, for example Critical Thinking Basics, Two Kinds of Reasoning, Clear Thinking, Critical Thinking based on Brooke Noel Moore and Richard Parker, Critical Thinking book. Curriculum programmer can be aware of the advantages of this book or other books that related to critical thinking and consider it to apply in English Language Teaching field. 


\section{References}

1. Cooper, J. (1995). Cooperative learning and critical thinking. Teaching ofPsychology, 22(1), 7e9.

2. Davies, M., \& Barnett, R. (2015). Introduction. In M. Davies, \& R. Barnett (Eds.), The Palgrave handbook of critical thinking in higher education (pp. 1-26). NewYork: Palgave Macmillan.

3. Ennis, R. H. (1985). A logical basis for measuring critical thinking skills. Educational Leadership, 43(2), 44-48.

4. Gadzella, B. M., \&Masten, W. G. (1998). Critical thinking and learning processes for students in two major fields. Journal of Instructional Psychology, 25(4), $256 e 261$.

5. Halpern, D. F. (1998). Teaching critical thinking for transfer across domains: Dispositions, skills, structure training, and metacognitivemonitoring. American Psychologist, 53(4), 449e455.

6. Kim, K. N. (2009). Exploring undergraduate students' active learning for enhancing their critical thinking and learning in a large class. Retrieved from http://gradworks.umi.com/33/80/3380934.html.

7. Lee, H. J., Lee, J., Makara, K. A., Fishman, B. J., \& Hong, Y. I. (2014). Does higher education foster critical and creative learners? An exploration of two McPeck, J. E. (1981). Critical thinking and education. New York, NY: St. Martin's Press.

8. Ornstein, A. C., \&Hunkins, F. P. (2004). Curriculum: Foundations, principles and issues (4th ed.). Boston, MA: Pearson.

9. Noel Moore,B\&Parker,R(2008).Critical thinking .Published by McGraw-Hill, an imprint of The McGraw-Hill Companies, Inc.

10. Sharma, M. \&eElbow, Gary S. (2000). Using Internet Primary Sources to Teach Critical Thinking Skills in Geography. Greenwood Publishing Group, Incorporated.

11. Tsai, C. C. (2001). A review and discussion of epistemological commitments metacognition, and critical thinking with suggestions on their enhancement in Internet-assisted chemistry classrooms. Journal of Chemical Education, 78(7), 970-975. 